NBER WORKING PAPER SERIES

\title{
DOES PRICE MATTER IN CHARITABLE GIVING? EVIDENCE FROM A LARGE-SCALE NATURAL FIELD EXPERIMENT
}

\author{
Dean Karlan \\ John A. List \\ Working Paper 12338 \\ http://www.nber.org/papers/w12338 \\ NATIONAL BUREAU OF ECONOMIC RESEARCH \\ 1050 Massachusetts Avenue \\ Cambridge, MA 02138 \\ June 2006
}

Karlan: Yale University, Department of Economics, Institute for Social and Policy Studies, and Innovations for Poverty Action; List: University of Chicago, Department of Economics and NBER. The authors thank James Andreoni, Ian Bateman, Richard Carson, Bill Harbaugh, Donald Green, Glenn Harrison, Sendhil Mullainathan, Lise Vesterlund, and participants at the University of Canterbury workshop on field experiments for comments. We thank Tomoko Harigaya and May Rostom from Innovations for Poverty Action for excellent research assistance. We thank the Organization for working with us on the field experiment and the anonymous donors for providing the matching grant. The views expressed herein are those of the author(s) and do not necessarily reflect the views of the National Bureau of Economic Research.

(O2006 by Dean Karlan and John A. List. All rights reserved. Short sections of text, not to exceed two paragraphs, may be quoted without explicit permission provided that full credit, including $\odot$ notice, is given to the source. 
Does Price Matter in Charitable Giving? Evidence From a Large-Scale Natural Field Experiment Dean Karlan and John A. List

NBER Working Paper No. 12338

June 2006

JEL No. C93, D12, D72, H41, L31, M31

\begin{abstract}
$\underline{\text { ABSTRACT }}$
We conducted a natural field experiment to explore the effect of price changes on charitable contributions. To operationalize our tests, we examine whether an offer to match contributions to a non-profit organization changes the likelihood and amount that an individual donates. Direct mail solicitations were sent to over 50,000 prior donors. We find that the match offer increases both the revenue per solicitation and the probability that an individual donates. While comparisons of the match treatments and the control group consistently reveal this pattern, larger match ratios (i.e., $\$ 3: \$ 1$ and $\$ 2: \$ 1)$ relative to smaller match ratios $(\$ 1: \$ 1)$ had no additional impact. The results have clear implications for practitioners in the design of fundraising campaigns and provide avenues for future empirical and theoretical work on charitable giving. Further, the data provide an interesting test of important methods used in cost-benefit analysis.

Dean Karlan

P.O. Box 208209

Yale University

New Haven, CT 06520-8209

dean.karlan@yale.edu
\end{abstract}

John A. List

Department of Economics

University of Chicago

1126 East 59th

Chicago, IL 60637

and NBER

jlist@uchicago.edu 
"There is an extraordinary amount of money available. The lack is of good ideas on how to get the basket under the apple tree." Fund-raising consultant Tony Kneer, The Economist, July $29^{\text {th }}, 2004$.

Private giving to charitable causes has significantly grown in the past several decades. Recent figures published by Giving USA show that in the U.S. charitable gifts of money have been $2 \%$ or more of GDP since 1998 , and more than $89 \%$ of Americans donate to charity (Sullivan, 2002). Experts predict that the combination of increased wealth and an ageing population will lead to an even higher level of gifts in the coming years (see, e.g., The Economist, July $\left.29^{\text {th }}, 2004\right) .{ }^{1}$ Such trends have left fundraisers, who are typically long on rules of thumb and short on hard scientific evidence, divided as to the most efficient means to attract these dollars. Indeed, even though the economics of charity has been well studied on the supply side, critical gaps remain on the demand side (Andreoni, 2005).

This study uses a large-scale natural field experiment to fill in some of these gaps. ${ }^{2}$ Specifically, we use a direct mail solicitation to explore whether, and to what extent, "price" matters in charitable fundraising. There is a rich and interesting literature that examines price effects via rebate mechanisms (such as changes in tax deductions) through which charitable contributions can be used to reduce one's tax burden (see, e.g., Clotfelter, 1985; Randolph, 1995; Peloza and Steel, 2005). ${ }^{3}$ Overall, it is fair to say that the four decades of empirical estimates of these supply-side effects vary widely, and it is difficult to make strong inferences

\footnotetext{
${ }^{1}$ Such conjectures are reinforced when one considers that some empirical evidence suggests that older agents tend to be more altruistic than younger agents (see, e.g., List, 2004).

${ }^{2}$ The term "natural field experiment" follows the classification scheme outlined in Harrison and List (2004).

3 The charitable donation tax deduction was enacted in the U.S. in 1917 and has become quite important to taxpayers: the aggregate amount of these deductions in the U.S. from 2001 to 2005 is estimated to be \$145 billion (Colombo, 2001).
} 
from the price effect estimates obtained from the naturally-occurring data (Auten et al., 2002). ${ }^{4}$ Laboratory experiments, on the other hand, typically find that the level of giving to others increases as price decreases (Andreoni and Miller 2002). In this study, we combine the attractive features of each of these lines of research by collecting data from a controlled field experiment in an actual fundraising effort.

A natural means to use a field experiment to explore the effects of price in this setting is to estimate the comparative static effects of large changes in rates of matching gifts, a commonly employed tool used by fundraisers to increase charitable gifts. A matching gift is a leadership gift that is a conditional commitment by a donor(s) to match the contributions of others at a given rate, up to the maximum amount the leadership donor is prepared to give. While the rate of matching is typically the result of an agreement between the fundraiser and the leadership donor, fundraising consultants ubiquitously note that increases in the matching ratio have noticeable power to influence future contributions. For instance, Dove (p. 15, 2000) warns that one should "never underestimate the power of a challenge gift" and that "obviously, a 1:1 match—every dollar that the donor gives is matched by another dollar—is more appealing than a 1:2 challenge......and a richer challenge (2:1) greatly adds to the match's attractiveness." Such strong claims have lead fundraisers to make use of the perceived extra power of larger matching ratios. For example, a recent $\$ 50$ million challenge grant gift to Drake University, which was among the forty largest gifts in U.S. history to an institution of higher education by an individual, was used to spur further gifts through 2:1 and 3:1 matching solicitations (Dove,

\footnotetext{
${ }^{4}$ Yet, the creative work of Auten et al. (2002) significantly advanced our understanding of the price effects, delivering persistent price elasticity estimates of -0.79 to -1.26 ; the elasticity of giving with respect to transitory price changes is much smaller, -0.40 to -0.61 .
} 
2000). Nevertheless, such "rules of thumb" are largely anecdotal, as little scientific study has been completed to examine such demand side claims. ${ }^{5}$

We take advantage of a unique opportunity to address these issues as part of a capital campaign at a liberal politically-oriented non-profit that focuses on social issues and civil liberties. The organization solicited contributions from more than 50,000 prior donors who currently reside in the U.S. This organization typically asks citizens to send tax-deductible donations several times per year and our field experiment was one of those fundraising drives. In this spirit, each group was solicited with a standard solicitation letter but we varied randomly the matching grant rate, matching grant amount, and suggested donation amount across the various treatment groups. ${ }^{6}$

We find that simply announcing that a match is available considerably increases the revenue per solicitation - by $19 \%$. In addition, the match offer significantly increases the probability that an individual donates-by $22 \%$. Yet, while the match treatments relative to a control group increase the probability of donating, larger match ratios- $\$ 3: \$ 1$ (i.e., $\$ 3$ match for every $\$ 1$ donated) and $\$ 2: \$ 1$-relative to smaller match ratios $(\$ 1: \$ 1)$ have no additional impact. The elasticity estimate of the price change from the baseline to the treatment groups, 0.30 , is near the lower range of the elasticity of giving with respect to transitory price changes reported in Auten et al. (2002). Elasticity estimates over the price range of the matching treatments are roughly zero, however. These results call into question the accepted wisdom of

\footnotetext{
${ }^{5}$ Exceptions are beginning to arise in other areas of fundraising, however. List and Lucking-Reiley (2002) and Landry et al. (2006) examine the efficacy of using a different type of leadership gift — challenge gifts - and find that such seed gifts announced by the fundraiser influence charitable contributions. In a related line of work, Frey and Meier (2005) explore interesting behavioural hypotheses using smaller changes in leadership gifts in a dichotomous choice fundraising experiment. And, in a much different environment and context, Eckel and Grossman (2003) use lab experiments to compare matching to an equivalent rebate of one's contributions in the context of a dictator game and find that matching contributions lead to significantly larger contributions than the rebate mechanism.

${ }^{6}$ Anonymous donors agreed to make a series of matching donations in conjunction with these experiments.
} 
fundraisers and raise the possibility that millions of dollars of potential gifts are foregone due to application of incorrect rules of thumb.

We also find, interestingly, that an exploration into whether treatment effects are spatially heterogeneous reveals that the matching gift result is driven by agents in states that voted for Bush in the 2004 presidential election: the match increases the revenue per solicitation by $55 \%$ in "red" states whereas there was little effect observed in "blue" states, suggesting that an individual's political environment also has the capacity to influence her giving behaviour.

These results have clear implications for practitioners in the design of fundraising campaigns, and provide avenues for future empirical and theoretical work on charitable giving. The results could also provide insights into certain areas of policymaking. For example, while price is central to our modelling of the individual response to public goods problems, one interpretation of our data is that there are important ranges of the price vector that do not influence solicitees' behavior. This result has potentially far-reaching policy implications. Practically, it speaks to state of the art methods used to measure non-market values for costbenefit assessments. The contingent valuation method (CVM), for example, is a survey technique commonly used to measure the economic value of a good or service. While hotly debated, some evidence in the CVM literature (e.g., Kahneman and Knetsch, 1992) suggests that individual values from CVM do not pass a "scope test," the value to a representative agent of saving 100 Peregrine falcons is not different from that of saving 100,000 (see also Diamond and Hausman, 1992). Of the dozens of studies that report data that passes or fails the scope test, we are unaware of any that use real stakes; rather they all ask "contingent" or hypothetical questions. In this light, our data might be viewed as a useful test of scope using an approach consistent with natural provision of a real public good. 
The remainder of our note proceeds as follows. The next section sketches a framework to aid in the interpretation of our data. Section II provides the experimental design and results. Section III concludes.

\section{Theoretical framework}

We present a simple model of the voluntary provision of public goods to provide the intuition for the set of factors that might underlie fundraisers' anecdotal evidence concerning matching grants. The model also supplies a means to interpret the data from our field experiment. We apply a variant of Andreoni's $(1989,1990)$ impure altruism model that recently has been used by Landry et al. (2006) to lend insights into door-to-door fundraising campaigns. $^{7}$

We assume that there are $n$ symmetric agents who derive utility from consuming a numeraire good, $y_{i}$, a public good, $G$, and their own contribution, $b_{i}$, to the public good. Each agent faces a budget constraint $y_{i}+b_{i} \leq w$ and derives ex post utility according to

(1) $\quad U_{i}=u\left(y_{i}\right)+\delta_{i} h(G)+\gamma f\left(b_{i}\right)$

where $u(\square, h(\square$, and $f(\square)$ are (strictly) increasing and concave; $\delta \in\{0,1\}$. The term $\gamma f(\square)$ depicts the "warm glow" effect from giving, where the parameter $\gamma$ might depend on the presence, and magnitude, of the promised matching grant monies. This implies that as long as $\gamma$ is positive, the agent receives utility from the mere act of contributing to the public good. Further, we assume that agents have incomplete information (or, more broadly, heterogeneous

\footnotetext{
${ }^{7}$ The model can be traced to a footnote in Becker (1974). Cornes and Sandler (1984) and Steinberg (1987) develop rich models of cases of mixed public/private goods. Andreoni (2004) provides an excellent overview of the general model as well as supply-side elasticity estimates. There are important alternative modeling approaches to our framework. For example, some have considered moral or group interested behavior (see, e.g., Laffont, 1975; Sen, 1977; and Sugden, 1984). In Sugden, (1984), for instance, agents adhere to a "moral constraint," whereby they compare themselves to the least generous person when making their contributions. Relatedly, in Bernheim's (1994) conformity model agents value status, and behavioral departures from the social norm impair status. Akerlof (1982) obtains similar conformity results by assuming deviations from social norms have direct utility consequences.
} 
perceptions) regarding the value of the public good at the time of receiving the solicitation, and thus attach $\delta$ to $h(G)$.

As described more patiently below, our treatments include cases where there is no match money, and cases where announced match money is to be used at various ratios $(\$ 1: \$ 1, \$ 2: \$ 1$, and $\$ 3: \$ 1)$. In the $\$ 1: \$ 1$ treatment, for instance, every dollar contributed is matched with $\$ 1$ from a leadership donor; thus invoking a "buy one, get one free" spirit. In this case, $G=2 \sum \mathrm{b}_{\mathrm{i}}$. Individuals give according to the first-order condition (for an interior solution):

$$
u^{\prime}(w-b)=\delta \Phi h^{\prime}(n \Phi b)+\gamma f^{\prime}(b)
$$

where $\Phi$ is the matching multiplier $-\Phi=2$ for $\$ 1: \$ 1, \Phi=3$ for $\$ 2: \$ 1$, and $\Phi=4$ for $\$ 3: \$ 1$. Concavity of the utility functions immediately implies that contributions are increasing in $\gamma$.

The first order condition provides intuition into why fundraisers might view matching as an attractive method to enhance contributions. First, the level of individual giving increases with enhancements in $\Phi$ due to the price effect since $G$ is the product of $b$ and $\Phi .{ }^{8}$ Second, the announcement of the availability of a leadership gift can reduce or eliminate any uncertainty about the credibility and value of a charitable organization or the particular task at hand, which also generates an increase in equilibrium contributions via $\delta$. Note a leadership grant could change $\delta$ via a quality-signalling effect (i.e., a change in the perception of the quality of nonprofit (Vesterlund, 2003)) or a timing-signalling effect (i.e., a change in the perception of the importance of this gift now to the non-profit). Implicit here we assume that $\delta$ is not influenced

\footnotetext{
${ }^{8}$ This contrasts with using leadership gifts as seed money, where $G$ results from the summation of $b$ and the level of seed monies available. Since seed money unconditionally increases the existing provision level of the public good, marginal utility may be reduced leading to lower individual contributions (see Landry et al., 2006). Andreoni (1998) uses a neat theoretical construct to explore a different effect of seed money in threshold public good provisioning: his model of charitable giving has multiple equilibria, and in the absence of seed money there exists a Nash equilibrium with zero charitable giving. The zero-contribution equilibrium can be eliminated, however, by initial commitments of seed money, which lower the remaining amount needed to be raised in the public fundraising campaign. Thus, in his model seed money is used as an elimination device rather than as a credibility device.
} 
by the ratio of a matching grant, but rather is influenced by the mere presence of a leadership gift. Thus, a first prediction of our simple model is that when the agent's utility for the public good is (strictly) increasing and concave, an announcement of a matching grant unequivocally increases total contributions. Likewise, under similar assumptions, our model predicts that contributions further increase as the fundraiser uses a more generous match ratio.

An important alternative set of predictions arises in our model when the number of agents, $n$, grows large. As Ribar and Wilhelm (2004) show, as $n$ increases the relative importance of one's utility from altruism diminishes and in the limit choices are driven solely by the warm glow component. As Andreoni (2004) points out, similar results can be achieved by allowing the size of the charity to grow. In this case, in the limit individuals might gain no marginal utility from the actual provision of the public good but simply purchase "moral satisfaction" when contributing. An empirical example of this variant of the model is described in Kahneman and Knetsch (1992). In their study, and in several subsequent studies (see, e.g., Baron and Greene, 2006 and the citations therein), a recurrent finding of hypothetical valuation experiments is that the value assigned to a public good does not depend on the quantity, or "scope," of the good in question. For example, Kahneman and Knetsch (1992) report that agents have a similar willingness to pay to improve sport fish stocks in British Columbia fresh water as they do for all of Canadian fresh water. Likewise, they report that famine relief in Ethiopia is valued similarly to famine relief across the whole continent of Africa. In effect, agents are insensitive to quantity, or "price" changes.

Such results are fiercely debated in the literature ${ }^{9}$ and certainly could be due to the hypothetical nature of the exercise, but they do represent an important variation of our model.

\footnotetext{
${ }^{9}$ Indeed, the Kahneman and Knetsch (1992) study remains one of the most highly cited papers ever published in the Journal of Environmental Economics and Management.
} 
If utility is solely a function of one's own contribution, $\gamma f\left(b_{i}\right)$, then a stark prediction is that there should be an insensitivity of individual contributions to changes in the matching grant rate, $\Phi$. Recent theories of social preferences refine this prediction by suggesting that agents are "conditionally" cooperative, or might be willing to contribute more to the public good if they learn that others have contributed, regardless of the magnitude of these previous contributions. The underlying mechanisms at work in such behavioural patterns include models of conformity, social norms, and reciprocity (see the discussion in Frey and Meier, 2005). In this light, the presence of any matching ratio might influence a warm glow effect from giving, $\gamma$, leading to higher individual contributions in the matching treatments compared to the controls.

Clearly, predictions from these alternative models are difficult to parse from a model where utility is flat over the relevant range of actual provision of the public good. In an effort to consider this possibility and provide a cleaner test of the competing predictions, we not only liberally change the match ratio, but also make use of treatments that liberally change the matching grant amount.

\section{Experimental design and results}

\section{Design}

The Organization is a liberal organization in the United States that works on social and political issues relating to particular civil liberties. According to a 2002 survey of its donors $70 \%$ of members are male, $60 \%$ are above 65 years old, $80 \%$ have a college education, $30 \%$ are Christian, $25 \%$ are of no particular religious identity, $15 \%$ are Jewish, and $85 \%$ first donated to the organization after 1992. In the 2000 Presidential election, $85 \%$ self-reported voting for Gore, $3 \%$ for Bush and $7 \%$ for Nader. 
Our sample frame consists of all 50,083 individuals who have given to the Organization at least once since $1991 .{ }^{10}$ Table 1 provides basic summary statistics and demonstrates that the assignment to treatment and control was orthogonal to observable demographic information and prior giving history. We assigned individuals randomly to two groups: a treatment "match" group (33,396, or $67 \%$ of the sample) and a control group (16,687 subjects, or $33 \%$ of the sample). All individuals received a four-page letter identical in all respects except two: (1) the treatment letters included an additional paragraph inserted at the top of the second page that announced that a "concerned fellow member" will match their donation, and (2) the reply card (see Figure 1) included in bold language the details of the match. For the control group, the reply card match language was replaced with a large logo of the organization.

The remainder of the letter, written and designed by the Organization, conformed to their typical fundraising practices. The letter discussed a pressing national issue (Supreme Court nominations) that the Organization was facing that particular month.

The specifics of the match offer were then randomized along three dimensions: the price ratio of the match, the maximum size of the matching gift across all donations, and the example donation amount suggested to the donor. Each of the sub-treatments (ratio, maximum size of match, and example amount) were assigned with equal probability.

Figure 1

\footnotetext{
${ }^{10}$ Individuals who have requested to be removed from mailing lists were excluded from this experiment, and large (over $\$ 1,000)$ prior donors were excluded.
} 


\section{MATCHING GRANT \\ NOW IS THE TIME TO GIVE!}

Troubled by the continued erosion of our constitutional rights, a concerned member has offered a matching grant [4 treatments: of $\$ 25,000$; of $\$ 50,000$; of $\$ 100,000$; blank] to encourage vou to contrihute to 1 at this time. To avoid losing the fight to defend our _ his member has announced the following match: [ 3 treatments: $\$ 1 ; \$ 2 ; \$ 3$ ] for every dollar you give. So, for every [3 treatments: HPC ${ }^{\star} 1.00$; $\mathrm{HPC}^{\star} 1.25$; $\mathrm{HPC}^{\star} 1.50$ ] you give, will actually receive $[\$ \mathrm{x}]$. Let's not lose this match -- please give today!

a) Maximum Size of the Matching Grant:

As shown in Figure 1, we test four treatments for the maximum matching grant amount: $\$ 25,000, \$ 50,000, \$ 100,000$, and unstated. Depending on the assumptions invoked, our theory is ambiguous as to whether a larger maximum amount (which makes the matching grant more likely to be relevant for the donor) will lead to a higher response rate and contribution level.

b) Price Ratio

We test three treatments for the price ratio (hereafter "ratio") of the match, $\$ 1: \$ 1, \$ 2: \$ 1$ and $\$ 3: \$ 1$. A $\$ 1: \$ 1$ ratio means that for every dollar the individual donates, the matching donor also contributes $\$ 1$, hence the charity receives $\$ 2$. The $\$ 2: \$ 1$ ratio means that for every dollar the individual donates, the matching donor contributes $\$ 2$, etc. (subject to the maximum amount across all donations, as discussed above). Again, as with the maximum match amount, the relationship between the price and likelihood to give and amount given depends critically on the modeling assumptions. 


\section{c) Ask Amount}

At the top of the reply card, the Organization includes three individual-specific suggested amounts equal to the individual's highest previous contribution, 1.25 times the highest previous contribution, and 1.50 times the highest previous contribution (all appropriately rounded). In the matching grant paragraph, we randomly chose one of the three suggested amounts from the reply card and used that as an example to illustrate the effect of the grant on the amount the charity would receive.

Within our model, a higher suggested amount may influence the nature of the warm glow effect, $\gamma$. If the "moral satisfaction" is deemed too costly, and the individual does not consider giving less than the example amount, then a higher example amount may make individuals less likely to contribute. In fact, Warwick (2003) finds that the net effect of lowering the ask amounts on the reply card typically increases the revenue (response rate typically increases, and amount given rarely changes). ${ }^{11}$

d) Heterogeneous treatment effects

Finally, since we are fundraising for a liberal politically-motivated group and sending solicitations to all 50 states, it is possible that the observed treatment effects are heterogeneous across different solicitees and different environments. For example, some researchers have argued that solicitee income level is a key determinant of the price elasticity of charitable donations (see, e.g., Auten et al., 2002; Anderson and Beier, 1999). Further, Lindahl (1995) identifies the length of relationship as a key variable in charitable fundraising. In addition, it is possible that utilitarian effects of contributing to our politically-motivated charity are different spatially due to the local political environments. To test for these effects, we merge our

\footnotetext{
${ }^{11}$ The "ask amount" refers to the amounts on the reply card, whereas we have tested the example amount within the matching grant offer language (holding constant the ask amounts). Hence, we have not tested exactly what it is reported in Warwick, yet the similarities warrant comparing the results.
} 
charitable giving data with (i) demographic data from the census, aggregated at the zip code level, (ii) state and county returns from the 2004 presidential election, and (iii) data from the Organization on frequency of their activities within each state.

\section{Experimental Results}

Table 2 presents the summary statistics and provides the core experimental results. In Table 2, we focus on two measures: a binary variable equal to one if any charitable contribution is made within one month of the direct mail solicitation, and a continuous variable for the amount given. As Panel A suggests, in total we raised $\$ 45,860$ in the fundraising drive: $\$ 13,566$ in the control groups and $\$ 32,294$ in the matching treatments (note that twice as many matching letters were sent). In the matching treatments, we raised $\$ 10,431, \$ 11,423$, and $\$ 10,439$ in the $\$ 1: \$ 1, \$ 2: \$ 1$, and $\$ 3: \$ 1$ treatments, respectively. This amounted to $\$ 0.813$, $\$ 0.937, \$ 1.026$, and $\$ 0.938$ in terms of revenue per solicitation in the control, $\$ 1: \$ 1, \$ 2: \$ 1$, and $\$ 3: \$ 1$ treatments, respectively. In terms of the other treatment variables, neither the match threshold nor the example amount seemed to have a meaningful influence on behaviour.

As a first basic examination of these giving rates, we use a distribution free test to explore whether the contribution amounts vary across treatment cells. Using a signed-rank Wilcoxon test, we find that the distribution of the gifts in the matching treatments is situated to the right of the distribution of the gifts in the control treatment at the $\mathrm{p}<.05$ level. Yet, the gift distributions across the various matching ratios are not significantly different from one another.

Next, we impose parametric assumptions to estimate the effect of the match (and its different features) on the likelihood of giving. Using probit models, we estimate the following two specifications: 


$$
Y_{i}=\alpha_{0}+\alpha_{1} T_{i}+\varepsilon_{i}
$$

$$
Y_{i}=\beta_{0}+\beta_{1} T_{i}+\beta_{2} T_{i} S_{i}+\beta_{3} T_{i} P_{i}+\beta_{4} T_{i} X_{i}+\varepsilon_{i},
$$

where $Y_{i}$ is a binary variable equal to one if individual $i$ donated within one month of receiving the solicitation. $T_{i}$ equals one if individual $i$ received any of the match offers. $S_{i}$ is a vector of three indicator variables for three of the four match sizes (the omitted category is unstated). $P_{i}$ is a vector of two indicator variables for two of the three price ratios (the omitted category is $\$ 1: \$ 1) . \quad X_{i}$ is a vector of two indicator variables for two of the three example amounts (the omitted category is the low example amount).

Table 3 presents the basic experimental results on the likelihood of contributing, and also examines heterogeneous treatment effects based on whether the individual had given already in 2005 and size of prior donation. We find the match is slightly more effective for those who had not yet given in 2005 (Columns 3 and 4 versus Columns 5 and 6), and we find that the match is significantly more effective for small prior donors (below the median $\$ 35$ gift) than large prior donors (Columns 7 and 8 versus Columns 9 and 10).

We also model the amount given as the outcome of interest. This analysis necessarily confounds two effects: the match may alter the type of person who responds (i.e., those predisposed to give large versus small amounts), as well as may alter the amount given conditional on giving. We estimate two specifications on both the full sample as well as the restricted sample of those who gave:

$$
\mathrm{A}_{\mathrm{i}}=\alpha_{0}+\alpha_{1} \mathrm{~T}_{\mathrm{i}}+\varepsilon_{\mathrm{i}}
$$

$$
A_{i}=\beta_{0}+\beta_{1} T_{i}+\beta_{2} T_{i} S_{i}+\beta_{3} T_{i} P_{i}+\beta_{4} T_{i} X_{i}+\varepsilon_{i},
$$


where $A_{i}$ is a continuous variable equal to the amount donated within one month of receiving the solicitation.

In Table 4, for the amount given $\left(A_{i}\right)$, Panel A reports results for the full sample, and Panel B reports results restricting the sample to the individuals who responded $\left(Y_{i}=1\right)$. The first combines the effect on response rate with the effect on amount given, thus providing the aggregate effect on charitable giving. This is particularly important from the fundraiser's perspective in determining optimal demand side considerations to maximize charitable giving. The second specification allows us to remove the average effect on the response rate from estimate, but two effects remain: the match may attract individuals with higher (or lower) typical giving amounts, and of course the match may change the amount an individual gives.

Our data also permit a rough estimation of the price elasticities of giving. When considering price movements from the control to the treatment cells, we estimate that elasticity of giving to be $-0.225,{ }^{12}$ and on sub-samples ranges from completely inelastic (states lost by Bush in the 2004 presidential election) to as large as -0.668 (states won by Bush in the 2004 presidential election). A useful comparison to these numbers is the estimated price elasticities of charitable tax deductions in the literature. Ever since Taussig's (1967) original estimates of the effect of changes in tax deductibility, four decades of research has provided estimates of the price elasticities. ${ }^{13}$ Our estimates are in the range of several previous studies. For example, Andreoni et al. (1996) report a price elasticity of -0.35 , Kingma (1989) estimates the elasticity for public radio contributions to be -0.43 (although Manzoor and Straub (2005) obtain different

\footnotetext{
${ }^{12}$ This is calculated from Table 2 Panel A Columns 1 and 2 on total dollars contributed (not including the match) per letter sent. The dollars raised increased by $19 \%$, and the average price to "buy" $\$ 1$ of the public good was $\$ 0.36$ (hence a decrease of $64 \%$ ), which implies an elasticity of -0.30 before taxes. Assuming a $25 \%$ marginal tax rate, the elasticity is then -0.225 .

${ }^{13}$ For early surveys see Clotfelter (1985) and Steinberg (1990). Peloza and Steel (2005) update these surveys and examine price elasticities with a meta-analysis.
} 
empirical estimates than Kingma (1989) using updated data). Likewise, our estimates are consistent with estimates of the elasticity of giving with respect to transitory price changes reported in Auten et al. (2002).

\section{Heterogeneous spatial treatment effects}

Table 2 Panels B and C provide summary statistics for blue (Kerry in 2004) and red states (Bush in 2004) to provide a sense of the spatial variability of our estimates. The results are stark. Overall, the response rate in blue states is higher than in red states, but is equivalent across the treatment and control groups (treatment $=2.1 \%$ and control $=2.0 \%$ ). Alternatively, the response rate in red states is significantly higher for the treatment than the control group (treatment $=2.3 \%$ and control $=1.5 \%$ ). Note that whereas the level of giving is much higher in the blue states than in the red states $(1.5 \%$ in red versus $2.0 \%$ in blue) under the control condition, the level of giving is roughly equivalent under the treatment condition $(2.3 \%$ in red versus $2.1 \%$ in blue). The summary statistics again show insignificant responsiveness for all other treatments — size and suggested amount — across both red and blue states.

Table 5 presents the econometric results by political environment of the individual's state (whereas Table 2 Panel B versus Panel C showed the summary statistics). We employ four measures: the vote share by state for Bush in the 2004 general presidential election, the vote share by county for Bush, and the number of court cases between 2002 and 2005 by state in which this Organization was either a party to or filed a brief, and the number of non-court case incidents between 2002 and 2005 by state reported in this Organization's newsletter to its members. These measures do not incorporate the intensity or importance of any given court case or incident. Hence they are noisy measures of the level of activity of this Organization 
within each state, and even noisier measures of the perception of the individuals of the local activity of the Organization in their state.

Table 5 Panel A shows clearly that the matching grant treatment was ineffective in blue states, yet effective in red states. The nonlinearity is striking, as noted by comparing Column 4 to Column 5: the differential response rate for states in which Bush narrowly lost (47.5\% to $49.9 \%$ ) was $0.2 \%$ points, whereas the differential response rate for states in which Bush narrowly won $(50.0 \%$ to $52.5 \%)$ was $1.6 \%$ points. Figure 2 plots the coefficients from the eight regressions in Table 5 Panel A. Figures 3 and 4 plot the response rates for each state, where each bubble is sized proportionally to the number of observations in the dataset. Figure 3 plots Bush's vote share on the x-axis and the overall response rate on the y-axis, demonstrating a slight downward slope: individuals in red states on average give less. Figure 4 plots Bush's vote share on the $\mathrm{x}$-axis and the differential response rate for the match on the $\mathrm{y}$-axis, demonstrating that no particular outlier states are driving the red/blue state difference.

Given the striking nature of our red/blue state result, it is important to take care to examine the robustness of this result. Note that analytically many explanations could be provided for why individuals in red versus blue states are more (or less) likely to give to a liberal Organization. The finding here, however, is that individuals in red states are more responsive to a matching grant offer, increasing the likelihood of contributing but not the amount given. The level effect for treatment groups is the same for red and blue states, whereas the control group for the red states is lower than the control group for the blue states. As noted earlier, some scholars have argued that income level is a key determinant of donor responsiveness (see, e.g., Lankford and Wyckoff, 1992; Auten et al., 2002). In this spirit, our results might be capturing underlying demographic differences between red and blue state 
contributors. To test for this, we merge our data with demographic census data aggregated at the zip code level. Table 6 shows these results. After interacting treatment with education, income, racial composition, age, household size, homeownership, and number of children, the coefficient on the interaction term of red and treatment remains strong and significant. We also test and reject that the red/blue state finding is driven by underlying differences in intensity of prior support for the Organization (Table 6 Column 1). ${ }^{14}$

These results, coupled with those discussed above, can lend insights into the broader applicability of the elasticities reported in the supply-side literature. Even though some studies have found negative and highly elastic price elasticities, many researchers have presented estimates that strongly challenge the view that tax incentives are a useful stimulus to giving (Peloza and Steel, 2005). The reported results have compelled some leading scholars to argue that the overall evidence on the price effect is decidedly mixed (see, e.g., Steinberg, 1990; Auten et al., 2002). Thus, we view our results as providing some confidence in the estimates in the

14 Given the robustness of these results, we empirically explored three specific possible explanations for the success of the matching grant in red but not blue states. First, we examined whether the immediate political environment of the individual (perhaps capturing the political leaning of those they interact with most often) matters, or whether it is indeed the state. We find that the political leaning of the county is irrelevant: individuals living in red counties in blue states behave just like individuals living in blue counties in blue states (and do not respond to the match), and individuals living in blue counties in red states behave just like individuals living in red counties in red states (and respond significantly to the match). Perhaps individuals are more responsive to price when they are considering goods for personal consumption? If individuals in red states perceive this Organization to be engaged in work that could directly affect their lives, then perhaps they are more responsive because of the private return to this Organization's work. This would suggest that the red versus blue state differential was masking an omitted variable, the Organization's local activity. In complementary models we examine this by including controls and interactions for the Organization's activity. Including these variables does not change the core result that the matching grant only worked in red states. Lastly, perhaps the red versus blue state merely captured an observable difference in the dedication or passion of the individual donors. With no survey data available on these individuals, the only measure we can use is prior giving. We run alternative models to examine whether the red versus blue state finding is robust to the inclusion of controls and interactions for prior giving. Indeed, those variables do not matter, and the red/blue state distinction remains the largest determinant of responding to the matching grant offer. A theory from social psychology, untestable directly with our data and experimental design, argues that individuals in a minority group have a stronger sense of social identity, and hence perhaps the peer nature (a social cue) of the matching grant acted as a catalyst to trigger the salience of this identity. This theory suggests that the "signal" ( $\delta$ in our model) generated by the leadership gift is effective as either a quality or timing signal, and that those in the minority political group are more responsive to such signals. 
most recent literature, but they serve to highlight that wide context-specific variation exists, not only based on demographics (e.g., income) but also on the timing and quality signal value of leadership gifts.

\section{Conclusions}

The supply side of the economics of charity typically utilizes a model of charitable giving that treats donations no differently than any other purchase the consumer makes. In this view, changes in tax deductibility emulate a change in the price of donating. This study pushes this literature in a new direction by focusing on the price effects on the demand side of charitable fundraising. In particular, we explore large price deviations by liberally changing the match rate in an actual charitable fundraising field experiment that targeted over 50,000 donors.

Several insights emerge. For example, we find that using leadership gifts as a matching offer considerably increases both the revenue per solicitation and the probability that an individual donates. This finding supports the anecdotal evidence among fundraising consultants on the efficacy of a matching mechanism. Yet, at odds with the conventional wisdom, we find that larger match ratios (i.e., $\$ 3: \$ 1$ and $\$ 2: \$ 1$ ) relative to smaller match ratios (\$1:\$1) have no additional impact. This result directly refutes the integrity of using larger match ratios, and stands in sharp contrast to current fundraising practices. In this light, our results have practical import.

Our data also provide a test of an important method used in cost-benefit analysis. Costbenefit analysis remains the hallmark of public policy decision making. Indeed, in the U.S. President Clinton's Executive Order 12866, which reaffirmed the earlier executive order from the Reagan Administration, requires that federal agencies consider costs, benefits, and 
economic impacts of regulations prior to their implementation. ${ }^{15}$ Estimation of benefits has been controversial, but the state of the art method is a stated preference approach (e.g., contingent valuation) if the total economic value (use and non-use) of a non-marketed good or service is sought. This approach has been criticized for several reasons, but perhaps most importantly for its hypothetical nature and the fact that few contingent studies pass a formal "scope" test (see, e.g. Diamond and Hausman, 1992; Kahneman and Knetsch, 1992). To the best of our knowledge, our data represent a first attempt to explore the "scope" of a public good that is actually provided in a naturally-occurring environment. In this regard, our data are consistent with the insensitivities observed in the CVM literature.

Finally, from a theoretical viewpoint, while our model provides insights into some of our results, the size and starkness of the differential response rate suggests that further theory would be useful. Future research in political psychology and social identity can help us better understand why the matching grant works in red states but not blue states. ${ }^{16}$ Furthermore, in light of the fact that Feldstein (1975) shows that price elasticities vary among the types of charitable organizations, it is important to explore whether, and to what extent, our results on heterogeneous spatial treatment effects are robust to other charity types such as religious, educational, and environmental organizations. Perhaps the nature of an organization's activities influences whether donors contribute to gain "moral satisfaction" or to increase the provision of

\footnotetext{
${ }^{15}$ The more than 100 federal agencies issue approximately 4,500 new rulemaking notices each year. About 25 percent of those 4,500 are significant enough to warrant Office of Management and Budget review. Of those, about 50-100 per year meet the necessary condition of being "economically significant" (more than $\$ 100$ million in either yearly benefits or costs). Every economically significant proposal receives a formal analysis of the benefits and costs by the agency.

${ }^{16}$ For example, our finding could be a political analog to the racial "acting white" phenomenon discussed in AustenSmith and Fryer (2006). The "acting white" phenomenon (being socially sanctioned for performing well in school) occurs when blacks are in the minority in a school. Even if minority status makes one's political identity stronger, this is not sufficient to generate our result (in fact, as-is, that may argue that those in red states should give more on average than those in blue states, all else equal, but we find the opposite). To fit our setting, one must also argue that this identity is latent (perhaps out of frustration with their local political outcomes), and then primed by the stimuli of the matching grant offer.
} 
the public good. As our model predicts, the motive of the donor will lead to significantly different response rates to manipulations of the price of the public good.

These results highlight the usefulness of potential future research examining the relative strength of non-price effects. The fact that responsiveness to a matching grant is partly determined by the political environment, rather than the economics of the matching grant itself, is important and consistent with recent work that reveals the relative importance of noneconomic factors in driving decision-making in charitable giving (Landry, Lange et al. 2006) and consumer credit (Bertrand, Karlan et al. 2005). Manipulations that make salient the importance or effectiveness of a gift can generate further donations (Vesterlund, 2003). Clearly, further work is necessary to understand which signals generate such effects. Such work will inform both positive and normative issues in economics. Further, such results will be useful for theorists and empiricists interested in obtaining deeper insights about the motivations behind the provision of public goods, as well as to non-profits interested in improving their fundraising practices. 


\section{References}

Akerlof, George A. (1982), "Labor Contracts as Partial Gift Exchange," Quarterly Journal of Economics, 97(4), pp. 543-569.

Andreoni, James. (1989), "Giving with Impure Altruism: Applications to Charity and Ricardian Equivalence." Journal of Political Economy 97: 1147-1458.

Andreoni, James. (1990), "Impure Altruism, and Donations to Public Goods: A Theory of Warm-Glow Giving." Economic Journal 100: 464-477.

Andreoni, James. (1995), "Cooperation in Public Goods Experiments: Kindness or Confusion?" American Economic Review 85(4): 891-904.

Andreoni, James. (1998), Toward a Theory of Charitable Fund-Raising. Journal of Political Economy, 106(6): 1186-1213.

Andreoni, James. (2004). "Philanthropy." In "Handbook of Giving, Reciprocity, and Altruism, L.A. Gerard-Varet, S.C, Kolm, and J.M. Ythier, Editors.

Andreoni, James. (2005). Leadership Giving in Charitable Fundraising. Journal of Public Economic Theory, forthcoming.

Andreoni, James., Gale, W. G., and Scholz, J. K. (1996). Charitable Contributions of Time and Money. University of Wisconsin - Madison Working Paper.

Andreoni, J. and J. Miller (2002). "Giving According to GARP: An Experimental Test of the Consistency of Preferences for Altruism." Econometrica 70(2): 737-753.

Anderson, D. and R. Beier (1999), "The Effect of a State Tax Credit on Giving to Community Foundations." American Economist 43(2): 66-72.

Austen-Smith, D. and R. Fryer, Jr. (2006). "An Economic Analysis of 'Acting White'." Quarterly Journal of Economics forthcoming.

Auten, G., H. Sieg, C.T. Clotfelter. 2002. "Charitable Giving, Income and Taxes: An Analysis of Panel Data." American Economic Review, 92: 371-82.

Baron, J. and J. D. Greene, (1996). "Determinants of insensitivity to quantity in valuation of public goods." Journal of Experimental Psychology 2: 107-125.

Becker, G.S. (1974). “A Theory of Social Interactions," Journal of Political Economy, 82:10631093.

Bernheim, B.D. (1994), “A Theory of Conformity.” Journal of Political Economy, 102(5), pp. $841-877$.

Bertrand, M., D. Karlan, S. Mullainathan, E. Shafir and J. Zinman (2005), "What's Psychology Worth? A Field Experiment in Consumer Credit Market," Yale University Economic Growth Center Discussion Paper. 918.

Clotfelter, C. (1985). Federal Tax Policy and Charitable Giving. Chicago, IL, University of Chicago Press.

Colombo, J. (2001). "The Marketing of Philanthropy and the Charitable Contributions Deduction: Integrating Theories for the Deduction and Tax Exemption." Wake Forest Law Review 36: 657-704.

Cornes R. and T. Sandler (1984). "Easy Riders, Joint Production and Public Goods." Economic Journal 94:580-598.

Diamond, P. A. and J. A. Hausman (1994). "Contingent Valuation: Is Some Number Better than No Number?" Journal of Economic Perspectives 8(4): 45-64.

Dove K.E. (2000), Conducting a Successful Capital Campaign. 2nd edition. San Francisco, Jossey-Bass. 510pp. 
Eckel, Catherine C. and Phillip J. Grossman (2003), "Rebate versus Matching: Does How We Subsidize Charitable Contributions Matter?," Journal of Public Economics, 87, 681701.

Feldstein, M. (1975), "The Income Tax and Charitable Contributions: Part II- The Impact on Religious, Educational and Other Organizations." National Tax Journal 28(2): 209-226.

Frey, B. S. and S. Meier (2004), "Social Comparisons and Pro-social Behavior: Testing "Conditional Cooperation" in a Field Experiment." American Economic Review 94(5): 1717-1722.

Harrison, G. and John. A. List (2004), "Field Experiments." Journal of Economic Literature XLII: $1009-1055$.

Kahneman, D. and J. L. Knetsch (1992), "Valuing Public Goods: The Purchase of Moral Satisfaction." Journal of Environmental Economics and Management 22: 57-70.

Kingma, B. R. (1989), “An Accurate Measurement of the Crowd-Out Effect, Income Effect, and Price Effect for Charitable Contributions.” Journal of Political Economy 97:1197-1207.

Laffont, Jean-Jacques (1975), "Macroeconomic Constraints, Economic Efficiency and Ethics: An Introduction to Kantian Economics," Economica, 42(168), pp. 430-437.

Landry, C., A. Lange, J.A. List, M.K. Price, and Nicholas Rupp (2006), "Toward an Understanding of the Economics of Charity: Evidence from a Field Experiment," Quarterly Journal of Economics, 121(2) forthcoming.

Lankford, H., and James Wyckoff (1992). "Primary and Secondary School Choice Among Public and Religious Alternatives." Economics of Education Review 11(4): 317-337.

Lindahl, W. E. (1995), "The major gift donor relationship: An analysis of donors and contributions." Nonprofit Management \& Leadership, 5(4), 411-432.

List, J.A. and D. Lucking-Reiley (2002), "The effects of seed money and refunds on charitable giving: experimental evidence from a University capital campaign," Journal of Political Economy 110, 215-233.

Manzoor, Sonia H. and Straub, John D. (2005), "The robustness of Kingma's crowd-out estimate: Evidence from new data on contributions to public radio." Public Choice 123: 463-476.

Peloza, J. a. P. S. (2005), "The Price Elasticities of Charitable Contributions: A Meta-Analysis." Journal of Public Policy \& Marketing 24(2): 260-272.

Randolph, W.C. (1995), "Dynamic Income, Progressive Taxes, and the Timing of Charitable Contributions," Journal of Political Economy 103: 709-38.

Ribar, C.D. and M.O. Wilhelm (2002). "Altruistic and Joy-of-Giving Motivations in Charitable Behavior." Journal of Political Economy 110: 425-457.

Sen, Amartya K. (1977), "Rational Fools: A Critique of the Behavioral Foundations of Economic Theory," Journal of Philosophy and Public Affairs, 6, pp. 317-44.

Steinberg, R. (1987), "Voluntary Donations and Public Expenditures in A Federalist System." American Economic Review 77: 24-36.

Sugden, Robert. (1984), "Reciprocity: The Supply of Public Goods Through Voluntary Contributions." Economic Journal 94, pp. 772-787.

Sullivan, A. (2002), "Affair of the Heart." Barron's 82(49): 28-29.

Steinberg, Richard (1990), “Taxes and Giving: New Findings" Voluntas, 1(2), 61-79.

Taussig, M. (1967), "Economic Aspects of the Personal Income Tax Treatment of Charitable Contricutions." National Tax Journal 20(1): 1-19. 
Vesterlund, Lise (2003), "The Informational Value of Sequential Fundraising." Journal of Public Economics 87: 627-657.

Warwick, M. (2003), Testing, Testing, 1, 2, 3. San Francisco, CA, Jossey-Bass. 
Table 1: Summary Statistics

Mean and Standard Deviations

\begin{tabular}{|c|c|c|c|}
\hline & $\begin{array}{l}\text { All } \\
(1)\end{array}$ & $\begin{array}{l}\text { Treatment } \\
\text { (2) }\end{array}$ & $\begin{array}{l}\text { Control } \\
\text { (3) }\end{array}$ \\
\hline \multicolumn{4}{|l|}{ STATE AND COUNTY } \\
\hline Red state & $\begin{array}{r}0.511 \\
(0.500)\end{array}$ & $\begin{array}{r}0.514 \\
(0.500)\end{array}$ & $\begin{array}{r}0.505 \\
(0.500)\end{array}$ \\
\hline Red county & $\begin{array}{r}0.510 \\
(0.500)\end{array}$ & $\begin{array}{r}0.512 \\
(0.500)\end{array}$ & $\begin{array}{r}0.507 \\
(0.500)\end{array}$ \\
\hline \multicolumn{4}{|l|}{ LEGAL } \\
\hline Non litigation & $\begin{array}{r}2.474 \\
(1.962)\end{array}$ & $\begin{array}{r}2.485 \\
(1.966)\end{array}$ & $\begin{array}{r}2.453 \\
(1.953)\end{array}$ \\
\hline Cases & $\begin{array}{r}1.500 \\
(1.155)\end{array}$ & $\begin{array}{r}1.499 \\
(1.157)\end{array}$ & $\begin{array}{r}1.502 \\
(1.152)\end{array}$ \\
\hline \multicolumn{4}{|l|}{ MEMBER ACTIVITY } \\
\hline \# of months since last donation & $\begin{array}{r}13.007 \\
(12.081)\end{array}$ & $\begin{array}{r}13.012 \\
(12.086)\end{array}$ & $\begin{array}{r}12.998 \\
(12.074)\end{array}$ \\
\hline Highest previous contribution & $\begin{array}{r}59.385 \\
(71.177)\end{array}$ & $\begin{array}{r}59.597 \\
(73.052)\end{array}$ & $\begin{array}{r}58.960 \\
(67.269)\end{array}$ \\
\hline \# of prior donations & $\begin{array}{r}8.039 \\
(11.394)\end{array}$ & $\begin{array}{r}8.035 \\
(11.390)\end{array}$ & $\begin{array}{r}8.047 \\
(11.404)\end{array}$ \\
\hline \# of years since initial donation & $\begin{array}{r}6.098 \\
(5.503)\end{array}$ & $\begin{array}{r}6.078 \\
(5.442)\end{array}$ & $\begin{array}{r}6.136 \\
(5.625)\end{array}$ \\
\hline \% already donated in 2005 & $\begin{array}{r}0.523 \\
(0.499)\end{array}$ & $\begin{array}{r}0.523 \\
(0.499)\end{array}$ & $\begin{array}{r}0.524 \\
(0.499)\end{array}$ \\
\hline Female & $\begin{array}{r}0.278 \\
(0.448)\end{array}$ & $\begin{array}{r}0.275 \\
(0.447)\end{array}$ & $\begin{array}{r}0.283 \\
(0.450)\end{array}$ \\
\hline Couple & $\begin{array}{r}0.092 \\
(0.289)\end{array}$ & $\begin{array}{r}0.091 \\
(0.288)\end{array}$ & $\begin{array}{r}0.093 \\
(0.290)\end{array}$ \\
\hline CENSUS DEMOGRAPHICS & & & \\
\hline Proportion white & $\begin{array}{r}0.830 \\
(0.172)\end{array}$ & $\begin{array}{r}0.831 \\
(0.171)\end{array}$ & $\begin{array}{r}0.830 \\
(0.173)\end{array}$ \\
\hline Proportion black & $\begin{array}{r}0.062 \\
(0.123)\end{array}$ & $\begin{array}{r}0.061 \\
(0.122)\end{array}$ & $\begin{array}{r}0.062 \\
(0.125)\end{array}$ \\
\hline Proportion aged between 18 - 39 yec & $\begin{array}{r}0.297 \\
(0.132)\end{array}$ & $\begin{array}{r}0.297 \\
(0.132)\end{array}$ & $\begin{array}{r}0.298 \\
(0.132)\end{array}$ \\
\hline Average household size & $\begin{array}{r}1.994 \\
(1.001)\end{array}$ & $\begin{array}{r}1.999 \\
(0.998)\end{array}$ & $\begin{array}{r}1.986 \\
(1.006)\end{array}$ \\
\hline Observations & 50,083 & 33,396 & 16,687 \\
\hline
\end{tabular}

Non litigation is the count of incidences relevant to this organization from each state reported in 2004-2005 (values range from zero to six) in the organization's monthly newsletter to donors. "Court cases" is the count of court cases from each state in 2004-2005 in which the organization was involved (values ranges from zero to four). 
Table 2: Mean Responses

Mean and Standard Errors

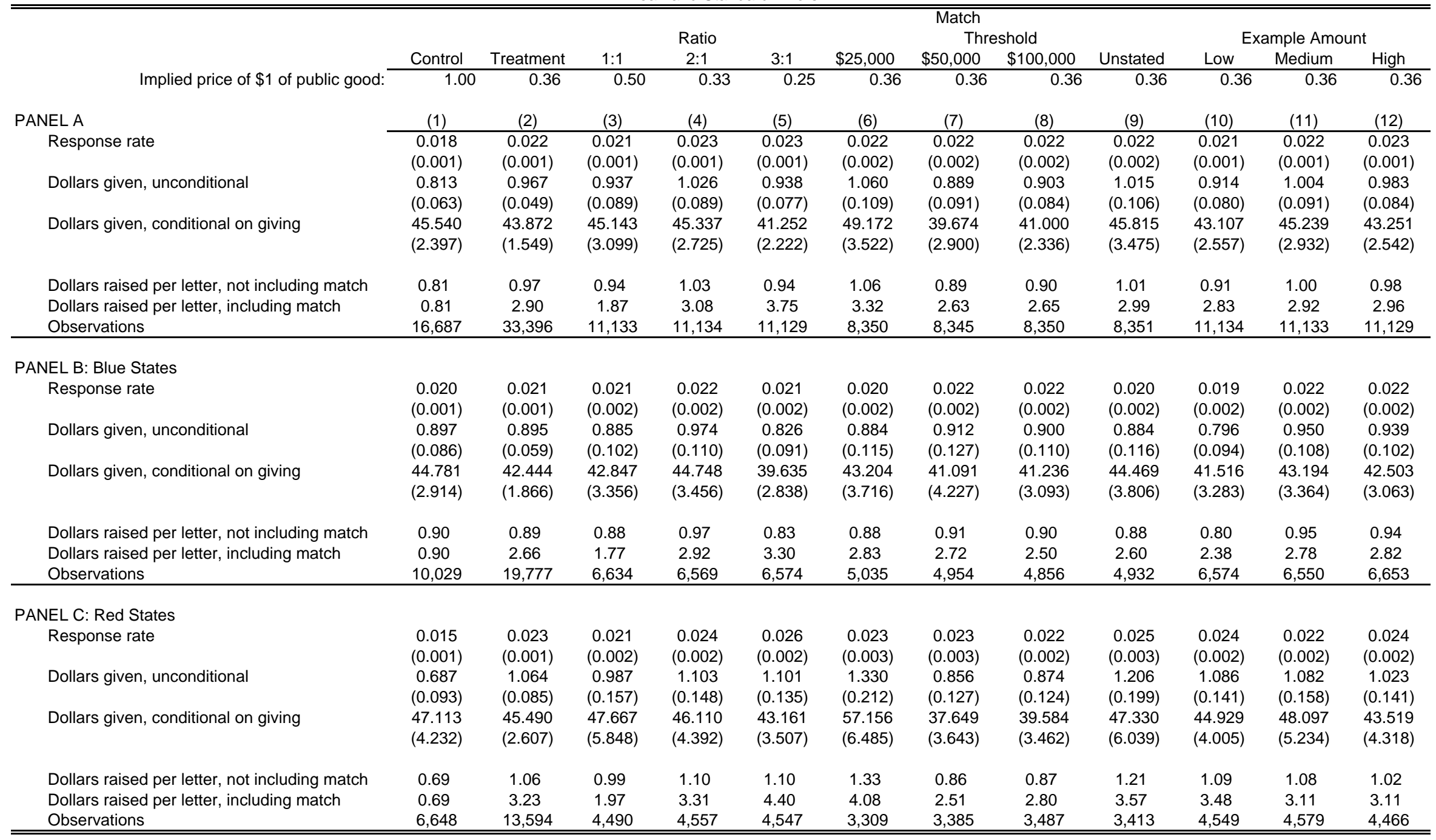


Table 3: Primary Regression Results

Probit, Dependent Variable $=$ Donated (Binary)

\begin{tabular}{|c|c|c|c|c|c|c|c|c|c|c|}
\hline & \multicolumn{2}{|c|}{ All } & \multicolumn{2}{|c|}{ Already Gave in 2005} & \multicolumn{2}{|c|}{ Had Not Given Yet in 2005} & \multicolumn{2}{|c|}{$\begin{array}{l}\text { Below Median Prior Donor } \\
\qquad(<\$ 35)\end{array}$} & \multicolumn{2}{|c|}{$\begin{array}{l}\text { Above Median Prior Donor } \\
\qquad>=\$ 35)\end{array}$} \\
\hline & $(1)$ & $(2)$ & (3) & $(4)$ & $(5)$ & $(6)$ & $(7)$ & $(8)$ & (9) & $(10)$ \\
\hline \multirow[t]{2}{*}{ Treatment } & $0.004^{\star * *}$ & 0.002 & $0.003^{\star *}$ & -0.001 & $0.005^{\star *}$ & 0.005 & $0.007^{\star * *}$ & 0.006 & 0.001 & -0.001 \\
\hline & $(0.001)$ & $(0.002)$ & $(0.001)$ & $(0.003)$ & $(0.002)$ & $(0.004)$ & $(0.002)$ & $(0.003)$ & $(0.002)$ & $(0.003)$ \\
\hline \multirow[t]{2}{*}{ Treatment * 2:1 ratio } & & 0.002 & & -0.001 & & 0.005 & & 0.003 & & 0.001 \\
\hline & & $(0.002)$ & & $(0.002)$ & & $(0.004)$ & & $(0.003)$ & & $(0.003)$ \\
\hline \multirow[t]{2}{*}{ Treatment * 3:1 ratio } & & 0.002 & & -0.001 & & 0.006 & & 0.004 & & 0.000 \\
\hline & & $(0.002)$ & & $(0.002)$ & & $(0.004)$ & & $(0.003)$ & & $(0.003)$ \\
\hline \multirow[t]{2}{*}{ Treatment * $\$ 25,000$ threshold } & & -0.001 & & 0.003 & & -0.004 & & $-0.005^{\star}$ & & 0.004 \\
\hline & & $(0.002)$ & & $(0.003)$ & & $(0.004)$ & & $(0.003)$ & & $(0.003)$ \\
\hline \multirow[t]{2}{*}{ Treatment * $\$ 50,000$ threshold } & & 0.000 & & 0.004 & & -0.003 & & 0.002 & & -0.002 \\
\hline & & $(0.002)$ & & $(0.003)$ & & $(0.004)$ & & $(0.003)$ & & $(0.003)$ \\
\hline \multirow[t]{2}{*}{ Treatment * $\$ 100,000$ threshold } & & -0.000 & & $0.006^{\star *}$ & & -0.006 & & -0.003 & & 0.003 \\
\hline & & $(0.002)$ & & $(0.003)$ & & $(0.003)$ & & $(0.003)$ & & $(0.003)$ \\
\hline \multirow[t]{2}{*}{ Treatment * Medium Example Amount } & & 0.001 & & 0.003 & & -0.001 & & 0.001 & & 0.001 \\
\hline & & $(0.002)$ & & $(0.002)$ & & $(0.003)$ & & $(0.003)$ & & $(0.003)$ \\
\hline \multirow[t]{2}{*}{ Treatment * High Example Amount } & & 0.001 & & 0.002 & & 0.001 & & 0.002 & & 0.001 \\
\hline & & $(0.002)$ & & $(0.002)$ & & $(0.003)$ & & $(0.003)$ & & $(0.003)$ \\
\hline Pseudo r-squared & 0.001 & 0.001 & 0.002 & 0.005 & 0.001 & 0.002 & 0.002 & 0.004 & 0.000 & 0.001 \\
\hline Observations & 50083 & 50083 & 26217 & 26217 & 23866 & 23866 & 24727 & 24727 & 25356 & 25356 \\
\hline
\end{tabular}

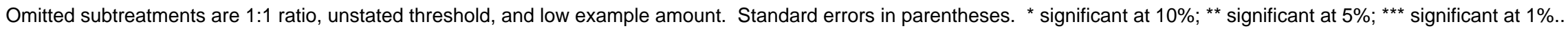


Table 4: Primary Regression Results

OLS, Dependent Variable $=$ Dollars Donated

\begin{tabular}{|c|c|c|c|c|c|c|c|c|c|c|}
\hline \multicolumn{11}{|c|}{ PANEL A: DOLLARS GIVEN, UNCONDITIONAL ON GIVING } \\
\hline & \multicolumn{2}{|c|}{ All } & \multicolumn{2}{|c|}{$\begin{array}{l}\text { Already Gave } \\
\text { in } 2005\end{array}$} & \multicolumn{2}{|c|}{$\begin{array}{l}\text { Did Not Give } \\
\text { in } 2005\end{array}$} & \multicolumn{2}{|c|}{$\begin{array}{c}\text { Below Median Prior } \\
\text { Donor }(<\$ 35)\end{array}$} & \multicolumn{2}{|c|}{$\begin{array}{c}\text { Above Median Prior } \\
\text { Donor }(>=\$ 35)\end{array}$} \\
\hline \multirow{3}{*}{ Treatment } & $(1)$ & $(2)$ & (3) & $(4)$ & (5) & $(6)$ & $(7)$ & $(8)$ & (9) & $(10)$ \\
\hline & $0.154^{*}$ & 0.118 & 0.152 & 0.102 & 0.157 & 0.142 & $0.222^{\star \star \star}$ & 0.108 & 0.100 & 0.153 \\
\hline & $(0.083)$ & $(0.151)$ & $(0.093)$ & $(0.170)$ & $(0.140)$ & $(0.255)$ & $(0.067)$ & $(0.122)$ & $(0.149)$ & $(0.274)$ \\
\hline Treatment * 1:1 ratio & & omitted & & omitted & & omitted & & omitted & & omitted \\
\hline Treatment $* 2: 1$ ratio & & $\begin{array}{c}0.089 \\
(0.117)\end{array}$ & & $\begin{array}{l}-0.027 \\
(0.132)\end{array}$ & & $\begin{array}{c}0.216 \\
(0.198)\end{array}$ & & $\begin{array}{c}0.134 \\
(0.095)\end{array}$ & & $\begin{array}{c}0.030 \\
(0.211)\end{array}$ \\
\hline Treatment * $3: 1$ ratio & & $\begin{array}{c}0.001 \\
(0.117)\end{array}$ & & $\begin{array}{l}-0.114 \\
(0.132)\end{array}$ & & $\begin{array}{c}0.121 \\
(0.197)\end{array}$ & & $\begin{array}{c}0.065 \\
(0.095)\end{array}$ & & $\begin{array}{l}-0.069 \\
(0.212)\end{array}$ \\
\hline Treatment * unstated maximum amount & & omitted & & omitted & & omitted & & omitted & & omitted \\
\hline Treatment * $\$ 25,000$ maximum amount & & $\begin{array}{c}0.045 \\
(0.135)\end{array}$ & & $\begin{array}{c}0.024 \\
(0.152)\end{array}$ & & $\begin{array}{c}0.068 \\
(0.228)\end{array}$ & & $\begin{array}{l}-0.051 \\
(0.110)\end{array}$ & & $\begin{array}{c}0.127 \\
(0.243)\end{array}$ \\
\hline Treatment $* \$ 50,000$ maximum amount & & $\begin{array}{l}-0.126 \\
(0.135)\end{array}$ & & $\begin{array}{c}0.066 \\
(0.152)\end{array}$ & & $\begin{array}{l}-0.337 \\
(0.228)\end{array}$ & & $\begin{array}{c}0.073 \\
(0.109)\end{array}$ & & $\begin{array}{l}-0.320 \\
(0.245)\end{array}$ \\
\hline Treatment * $\$ 100,000$ maximum amount & & $\begin{array}{l}-0.111 \\
(0.135)\end{array}$ & & $\begin{array}{c}0.046 \\
(0.152)\end{array}$ & & $\begin{array}{l}-0.289 \\
(0.228)\end{array}$ & & $\begin{array}{l}-0.074 \\
(0.109)\end{array}$ & & $\begin{array}{l}-0.146 \\
(0.244)\end{array}$ \\
\hline Treatment * Low Example Amount & & omitted & & omitted & & omitted & & omitted & & omitted \\
\hline Treatment * Medium Example Amount & & $\begin{array}{c}0.090 \\
(0.117)\end{array}$ & & $\begin{array}{l}0.22{ }^{\star} \\
(0.132)\end{array}$ & & $\begin{array}{l}-0.053 \\
(0.197)\end{array}$ & & $\begin{array}{c}0.084 \\
(0.095)\end{array}$ & & $\begin{array}{c}0.092 \\
(0.212)\end{array}$ \\
\hline Treatment * High Example Amount & & $\begin{array}{c}0.069 \\
(0.117)\end{array}$ & & $\begin{array}{l}-0.032 \\
(0.132)\end{array}$ & & $\begin{array}{c}0.179 \\
(0.197)\end{array}$ & & $\begin{array}{c}0.098 \\
(0.095)\end{array}$ & & $\begin{array}{c}0.038 \\
(0.212)\end{array}$ \\
\hline Constant & $\begin{array}{l}0.813^{\star \star *} \\
(0.067)\end{array}$ & $\begin{array}{l}0.813^{\star \star *} \\
(0.067)\end{array}$ & $\begin{array}{l}0.423^{\star \star \star} \\
(0.076)\end{array}$ & $\begin{array}{l}0.423^{\star \star \star} \\
(0.076)\end{array}$ & $\begin{array}{l}1.241^{\star \star \star} \\
(0.114)\end{array}$ & $\begin{array}{l}1.241^{\star \star \star} \\
(0.114)\end{array}$ & $\begin{array}{l}0.405^{\star \star \star} \\
(0.055)\end{array}$ & $\begin{array}{l}0.405^{\star \star \star} \\
(0.055)\end{array}$ & $\begin{array}{l}1.202^{\star \star \star} \\
(0.121)\end{array}$ & $\begin{array}{l}1.202^{\star \star \star} \\
(0.121)\end{array}$ \\
\hline R-squared & 0.000 & 0.000 & 0.000 & 0.000 & 0.000 & 0.000 & 0.000 & 0.000 & 0.000 & 0.000 \\
\hline Observations & 50083 & 50083 & 26217 & 26217 & 23866 & 23866 & 24727 & 24727 & 25356 & 25356 \\
\hline \multicolumn{11}{|c|}{ PANEL B: DOLLARS GIVEN, CONDITIONAL ON GIVING } \\
\hline & $\mathrm{A}$ & & \multicolumn{2}{|c|}{$\begin{array}{c}\text { Already Gave } \\
\text { in } 2005\end{array}$} & \multicolumn{2}{|c|}{$\begin{array}{l}\text { Did Not Give } \\
\text { in } 2005\end{array}$} & \multicolumn{2}{|c|}{$\begin{array}{c}\text { Below Median Prior } \\
\text { Donor }(<\$ 35)\end{array}$} & \multicolumn{2}{|c|}{$\begin{array}{c}\text { Above Median Prior } \\
\text { Donor }(>=\$ 35)\end{array}$} \\
\hline $\begin{array}{l}\text { Treatment } \\
\text { Treatment * 1:1 ratio }\end{array}$ & $\begin{array}{l}-1.668 \\
(2.872)\end{array}$ & $\begin{array}{c}0.686 \\
(5.036) \\
\text { omitted }\end{array}$ & $\begin{array}{l}-0.180 \\
(6.571)\end{array}$ & $\begin{array}{c}15.884 \\
(11.781) \\
\text { omitted }\end{array}$ & $\begin{array}{l}-2.425 \\
(3.104)\end{array}$ & $\begin{array}{l}-3.419 \\
(5.426) \\
\text { omitted }\end{array}$ & $\begin{array}{c}2.523 \\
(2.162)\end{array}$ & $\begin{array}{l}-0.526 \\
(3.678) \\
\text { omitted }\end{array}$ & $\begin{array}{c}0.749 \\
(4.598)\end{array}$ & $\begin{array}{l}12.942 \\
(8.432) \\
\text { omitted }\end{array}$ \\
\hline Treatment * 2:1 ratio & & $\begin{array}{l}-0.138 \\
(3.811)\end{array}$ & & $\begin{array}{c}4.720 \\
(8.231)\end{array}$ & & $\begin{array}{l}-0.862 \\
(4.211)\end{array}$ & & $\begin{array}{c}2.368 \\
(2.762)\end{array}$ & & $\begin{array}{l}-1.228 \\
(6.421)\end{array}$ \\
\hline Treatment * $3: 1$ ratio & & $\begin{array}{l}-4.112 \\
(3.815)\end{array}$ & & $\begin{array}{l}-3.393 \\
(8.295)\end{array}$ & & $\begin{array}{l}-3.637 \\
(4.207)\end{array}$ & & $\begin{array}{l}-0.742 \\
(2.746)\end{array}$ & & $\begin{array}{l}-4.689 \\
(6.554)\end{array}$ \\
\hline Treatment * unstated maximum amount & & omitted & & omitted & & omitted & & omitted & & omitted \\
\hline Treatment * $\$ 25,000$ maximum amount & & $\begin{array}{c}3.711 \\
(4.385)\end{array}$ & & $\begin{array}{l}-12.250 \\
(10.464)\end{array}$ & & $\begin{array}{l}8.181^{\star} \\
(4.695)\end{array}$ & & $\begin{array}{c}3.740 \\
(3.244)\end{array}$ & & $\begin{array}{l}-8.926 \\
(7.320)\end{array}$ \\
\hline Treatment * $\$ 50,000$ maximum amount & & $\begin{array}{l}-6.160 \\
(4.342)\end{array}$ & & $\begin{array}{l}-15.497 \\
(10.269)\end{array}$ & & $\begin{array}{l}-5.443 \\
(4.675)\end{array}$ & & $\begin{array}{c}0.653 \\
(2.983)\end{array}$ & & $\begin{array}{l}-10.915 \\
(7.933)\end{array}$ \\
\hline Treatment * $\$ 100,000$ maximum amount & & $\begin{array}{l}-4.868 \\
(4.357)\end{array}$ & & $\begin{array}{l}-22.391^{\star *} \\
(10.054)\end{array}$ & & $\begin{array}{l}-0.946 \\
(4.747)\end{array}$ & & $\begin{array}{c}0.114 \\
(3.145)\end{array}$ & & $\begin{array}{c}-18.830^{\star *} \\
(7.376)\end{array}$ \\
\hline Treatment * Low Example Amount & & omitted & & omitted & & omitted & & omitted & & omitted \\
\hline Treatment * Medium Example Amount & & $\begin{array}{c}2.631 \\
(3.822)\end{array}$ & & $\begin{array}{c}4.429 \\
(8.446)\end{array}$ & & $\begin{array}{c}1.392 \\
(4.198)\end{array}$ & & $\begin{array}{c}2.615 \\
(2.758)\end{array}$ & & $\begin{array}{c}0.906 \\
(6.454)\end{array}$ \\
\hline Treatment * High Example Amount & & $\begin{array}{c}0.284 \\
(3.789)\end{array}$ & & $\begin{array}{l}-12.605 \\
(8.722)\end{array}$ & & $\begin{array}{c}5.000 \\
(4.103)\end{array}$ & & $\begin{array}{c}1.833 \\
(2.719)\end{array}$ & & $\begin{array}{l}-1.745 \\
(6.438)\end{array}$ \\
\hline Constant & $\begin{array}{c}45.540 \star \star \star \star \\
(2.423)\end{array}$ & $\begin{array}{c}45.540^{\star \star \star} \\
(2.422)\end{array}$ & $\begin{array}{c}49.200 * \star \star \\
(5.623)\end{array}$ & $\begin{array}{c}49.200^{\star \star \star} \\
(5.596)\end{array}$ & $\begin{array}{c}44.309 * \star \star \\
(2.605)\end{array}$ & $\begin{array}{c}44.309^{\star \star \star} \\
(2.599)\end{array}$ & $\begin{array}{c}22.134^{\star \star \star *} \\
(1.859)\end{array}$ & $\begin{array}{c}22.134^{\star \star \star} \\
(1.864)\end{array}$ & $\begin{array}{c}68.946 * \star \star \\
(3.786)\end{array}$ & $\begin{array}{c}68.946^{\star \star \star} \\
(3.785)\end{array}$ \\
\hline R-squared & 0.000 & 0.008 & 0.000 & 0.035 & 0.001 & 0.015 & 0.002 & 0.009 & 0.000 & 0.016 \\
\hline Observations & 1034 & 1034 & 280 & 280 & 754 & 754 & 571 & 571 & 463 & 463 \\
\hline
\end{tabular}

Standard errors in parentheses. * significant at 10\%; ** significant at 5\%; ${ }^{\star \star \star}$ significant at $1 \%$. 
Table 5: Heterogenous Treatment Effects by Political Environment

Dependent Variable $=$ Donated $($ Binary $)$

Probit

PANEL A: Subsamples by Bush Vote Share

\section{Treatment}

Constant

Pseudo r-squared

Observations

PANEL B: Analysis by County Type

Treatment

Pseudo r-squared

Observations

PANEL C: Analysis by Activity of the Organization

Treatment

Red state

Treatment * red state

Non litigation

Treatment * Non litigation

Court cases

Treatment * Court cases

Pseudo r-squared

Observations

"Non litigation" is the count of incidences relevant to this organization from each state reported in 2004-2005 (values range from zero to six) in the organization's monthly newsletter to donors. "Court cases" is the count of court cases from each state in 2004-2005 in which the organization was involved (values ranges from zero to four). Standard errors in parentheses. * significant at 10\%; ** significant at $5 \%$; ${ }^{* \star}$ significant at $1 \%$.

Each Column Restricts the Sample Frame to Respondents in States with the Specified Bush Vote Shares

\begin{tabular}{|c|c|c|c|c|c|c|c|}
\hline$\leq 40 \%$ & $\begin{array}{c}>40 \% \& \\
\leq 45 \%\end{array}$ & $\begin{array}{l}>45 \% \& \\
\leq 47.5 \%\end{array}$ & $\begin{array}{c}>47.5 \% \& \\
\quad \leq 50 \%\end{array}$ & $\begin{array}{l}>50 \% \& \\
\leq 52.5 \%\end{array}$ & $\begin{array}{c}>52.5 \% \text { \& } \\
\leq 55 \%\end{array}$ & $\begin{array}{c}>55 \% \& \\
\leq 60 \%\end{array}$ & $>60 \%$ \\
\hline (1) & (2) & (3) & (4) & (5) & (6) & (7) & (8) \\
\hline 0.004 & -0.001 & 0.006 & 0.002 & $0.016^{\star \star \star}$ & $0.006^{*}$ & 0.007 & $0.008^{\star \star}$ \\
\hline (0.005) & (0.002) & (0.005) & (0.004) & $(0.006)$ & (0.003) & (0.005) & (0.004) \\
\hline $0.015^{\star \star \star}$ & 0.021 *** & $0.021^{\star \star *}$ & $0.019 * \star \star *$ & $0.017^{\star \star *}$ & $0.015^{\star \star *}$ & $0.014^{\star * *}$ & $0.012^{\star * *}$ \\
\hline$(0.004)$ & $(0.002)$ & $(0.004)$ & $(0.003)$ & $(0.005)$ & $(0.003)$ & $(0.004)$ & $(0.003)$ \\
\hline 0.000 & 0.000 & 0.000 & 0.000 & 0.002 & 0.000 & 0.001 & 0.001 \\
\hline 2522 & 18176 & 3789 & 5319 & 3975 & 7061 & 3903 & 5303 \\
\hline
\end{tabular}

Red County Blue County Red County Blue County

\begin{tabular}{cccc}
$\begin{array}{c}\text { in a } \\
\text { Red State }\end{array}$ & $\begin{array}{c}\text { in a } \\
\text { Red State }\end{array}$ & $\begin{array}{c}\text { in a } \\
\text { Blue State }\end{array}$ & $\begin{array}{c}\text { in a } \\
\text { Blue State }\end{array}$ \\
\hline$(1)$ & $(2)$ & $(3)$ & $(4)$ \\
\hline $0.010^{\star \star \star}$ & $0.007^{\star \star}$ & 0.000 & 0.001 \\
$(0.002)$ & $(0.003)$ & $(0.003)$ & $(0.002)$ \\
& & & \\
0.005 & 0.003 & 0.000 & 0.000 \\
13675 & 6553 & 11826 & 17872
\end{tabular}

Full Sample Full Sample Full Sample

\begin{tabular}{ccc}
$(1)$ & $(2)$ & $(3)$ \\
\hline 0.001 & 0.003 & 0.003 \\
$(0.002)$ & $(0.003)$ & $(0.003)$ \\
$-0.006^{\star \star \star}$ & $-0.006^{\star \star \star}$ & $-0.007^{\star \star \star}$ \\
$(0.002)$ & $(0.002)$ & $(0.003)$ \\
$0.009^{\star \star \star}$ & $0.008^{\star \star \star}$ & $0.008^{\star \star}$ \\
$(0.003)$ & $(0.004)$ & $(0.004)$ \\
0.000 & & 0.000 \\
$(0.001)$ & & $(0.001)$ \\
0.000 & & 0.000 \\
$(0.001)$ & & $(0.001)$ \\
& 0.000 & 0.000 \\
& $(0.001)$ & $(0.001)$ \\
& -0.001 & -0.001 \\
& $(0.001)$ & $(0.001)$
\end{tabular}

$\begin{array}{lll}0.002 & 0.002 & 0.002 \\ 50046 & 50046 & 50046\end{array}$

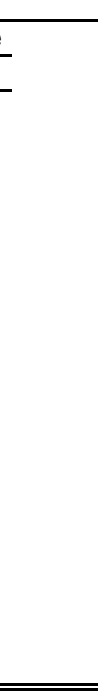


Table 6: Census Demographic Analysis Regressions

Dependent Variable $=$ Donated $($ Binary $)$

\begin{tabular}{|c|c|c|c|c|c|c|c|c|c|c|}
\hline & (1) & (2) & (3) & $(4)$ & (5) & (6) & $(7)$ & $(8)$ & (9) & (10) \\
\hline Treatment & 0.002 & 0.000 & 0.000 & -0.005 & 0.004 & 0.003 & 0.002 & 0.003 & -0.001 & 0.006 \\
\hline Red state & $\begin{array}{c}(0.002) \\
-0.006^{\star \star \star} \\
(0.002)\end{array}$ & $\begin{array}{l}(0.002) \\
-0.005^{*} \\
(0.003)\end{array}$ & $\begin{array}{c}(0.002) \\
-0.005^{\star *} \\
(0.003)\end{array}$ & $\begin{array}{c}(0.004) \\
-0.005^{\star *} \\
(0.003)\end{array}$ & $\begin{array}{c}(0.007) \\
-0.005^{\star \star} \\
(0.003)\end{array}$ & $\begin{array}{l}(0.002) \\
-0.005^{\star \star} \\
(0.003)\end{array}$ & $\begin{array}{l}(0.002) \\
-0.005^{\star *} \\
(0.003)\end{array}$ & $\begin{array}{l}(0.002) \\
-0.005^{\star \star} \\
(0.003)\end{array}$ & $\begin{array}{l}(0.002) \\
-0.005^{\star *} \\
(0.003)\end{array}$ & $\begin{array}{l}(0.010) \\
-0.005^{\star \star} \\
(0.003)\end{array}$ \\
\hline Treatment * red state & $\begin{array}{c}0.009 * \star \star \\
(0.003)\end{array}$ & $\begin{array}{l}0.009^{\star \star} \\
(0.004)\end{array}$ & $\begin{array}{l}0.009 * * \\
(0.004)\end{array}$ & $\begin{array}{l}0.010^{* *} \\
(0.004)\end{array}$ & $\begin{array}{l}0.009 * * \\
(0.004)\end{array}$ & $\begin{array}{l}0.008^{\star *} \\
(0.004)\end{array}$ & $\begin{array}{l}0.010^{\star \star} \\
(0.004)\end{array}$ & $\begin{array}{l}0.009^{\star \star} \\
(0.004)\end{array}$ & $\begin{array}{l}0.009^{\star *} \\
(0.004)\end{array}$ & $\begin{array}{l}0.009^{\star *} \\
(0.004)\end{array}$ \\
\hline First donation five or more years ago (binary) & $\begin{array}{c}0.004 \\
(0.002)\end{array}$ & & & & & & & & & \\
\hline Treatment * first donation five or more years ago & $\begin{array}{c}0.000 \\
(0.003)\end{array}$ & & & & & & & & & \\
\hline Highest previous amount donated & $\begin{array}{c}0.002 \\
(0.002)\end{array}$ & & & & & & & & & \\
\hline Treatment * highest previous amount donated & $\begin{array}{l}-0.001 \\
(0.002)\end{array}$ & & & & & & & & & \\
\hline Proportion white & & $\begin{array}{c}-0.008^{\star \star} \\
(0.004)\end{array}$ & & & & & & & & $\begin{array}{l}-0.003 \\
(0.007)\end{array}$ \\
\hline Treatment * proportion white & & $\begin{array}{c}0.000 \\
(0.000)\end{array}$ & & & & & & & & $\begin{array}{l}0.000 \\
(0.000)\end{array}$ \\
\hline Proportion black & & & $\begin{array}{c}0.008 \\
(0.009)\end{array}$ & & & & & & & $\begin{array}{l}0.004 \\
(0.011)\end{array}$ \\
\hline Treatment * proportion black & & & $\begin{array}{c}0.004 \\
(0.011)\end{array}$ & & & & & & & $\begin{array}{l}0.003 \\
(0.012)\end{array}$ \\
\hline Proportion aged between 18 - 39 years & & & & $\begin{array}{l}-0.019^{\star} \\
(0.010)\end{array}$ & & & & & & $\begin{array}{l}-0.027^{\star *} \\
(0.012)\end{array}$ \\
\hline Treatment * Proportion aged 18 - 39 years & & & & $\begin{array}{c}0.017 \\
(0.012)\end{array}$ & & & & & & $\begin{array}{l}0.015 \\
(0.014)\end{array}$ \\
\hline Average household size & & & & & $\begin{array}{c}0.001 \\
(0.003)\end{array}$ & & & & & $\begin{array}{l}0.005 \\
(0.004)\end{array}$ \\
\hline Treatment \& average household size & & & & & $\begin{array}{l}-0.001 \\
(0.003)\end{array}$ & & & & & $\begin{array}{l}-0.005 \\
(0.004)\end{array}$ \\
\hline Proportion with income above median & & & & & & $\begin{array}{l}-0.000 \\
(0.003)\end{array}$ & & & & $\begin{array}{l}0.001 \\
(0.003)\end{array}$ \\
\hline Treatment * proportion with income above median & & & & & & $\begin{array}{l}-0.004 \\
(0.003)\end{array}$ & & & & $\begin{array}{l}-0.003 \\
(0.004)\end{array}$ \\
\hline Proportion house owner & & & & & & & $\begin{array}{l}0.000 \\
(0.003)\end{array}$ & & & $\begin{array}{l}-0.002 \\
(0.003)\end{array}$ \\
\hline Treatment * proportion house owner & & & & & & & $\begin{array}{l}-0.003 \\
(0.003)\end{array}$ & & & $\begin{array}{l}-0.001 \\
(0.004)\end{array}$ \\
\hline Proportion with education above median & & & & & & & & $\begin{array}{l}-0.001 \\
(0.003)\end{array}$ & & $\begin{array}{l}0.000 \\
(0.003)\end{array}$ \\
\hline Treatment * proportion with education above median & & & & & & & & $\begin{array}{l}-0.004 \\
(0.003)\end{array}$ & & $\begin{array}{l}-0.003 \\
(0.003)\end{array}$ \\
\hline Above median number of children & & & & & & & & & $\begin{array}{l}-0.003 \\
(0.003)\end{array}$ & $\begin{array}{l}-0.008^{* *} \\
(0.004)\end{array}$ \\
\hline Treatment * Above median number of children & & & & & & & & & $\begin{array}{l}0.002 \\
(0.003)\end{array}$ & $\begin{array}{l}0.009^{\star} \\
(0.005)\end{array}$ \\
\hline Pseudo r-squared & 0.005 & 0.002 & 0.002 & 0.002 & 0.002 & 0.003 & 0.002 & 0.003 & 0.002 & 0.005 \\
\hline Observations & 50036 & 41684 & 41684 & 41684 & 41699 & 41699 & 41699 & 41699 & 41699 & 41684 \\
\hline
\end{tabular}


Figure 1

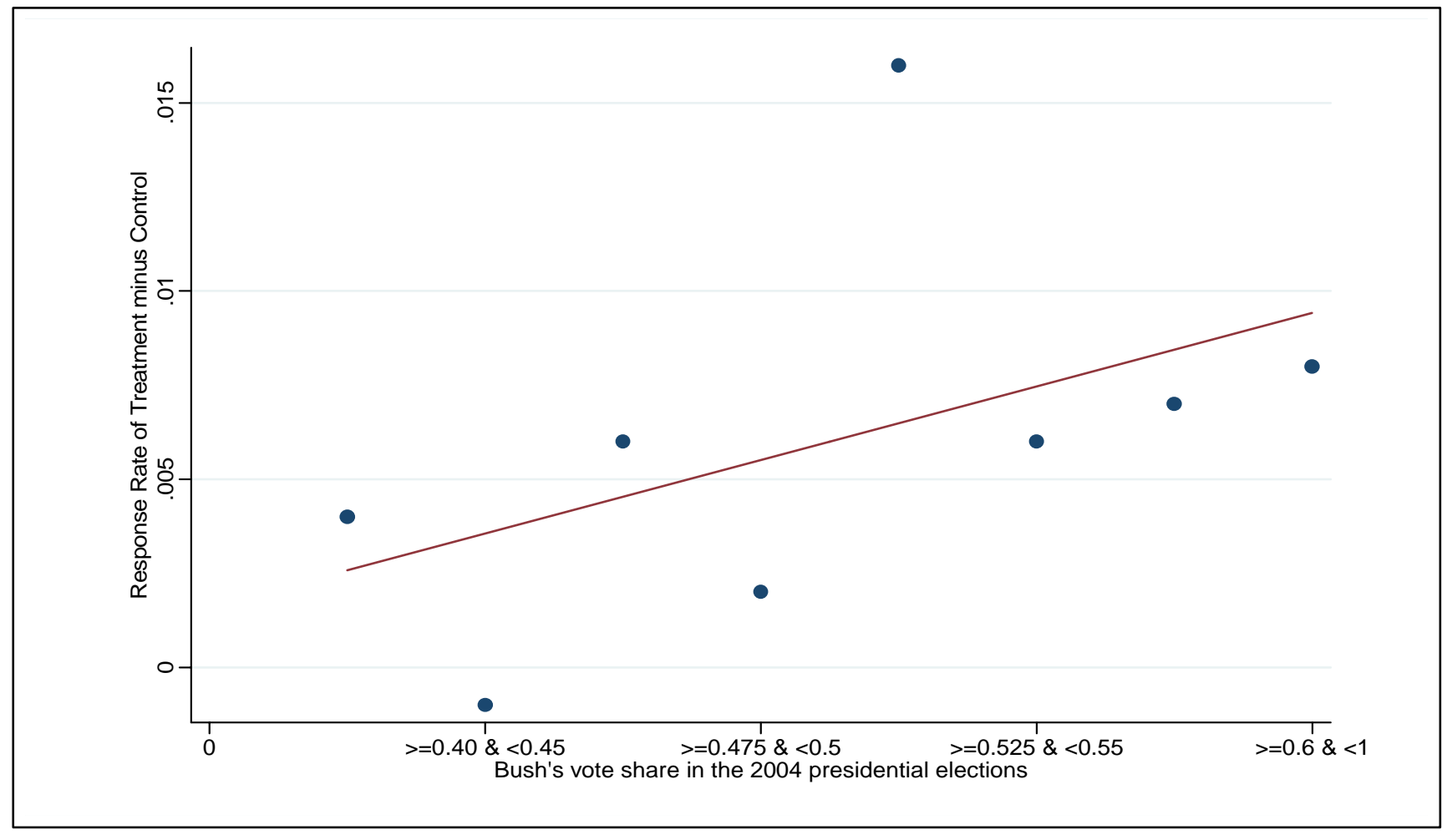


Figure 2

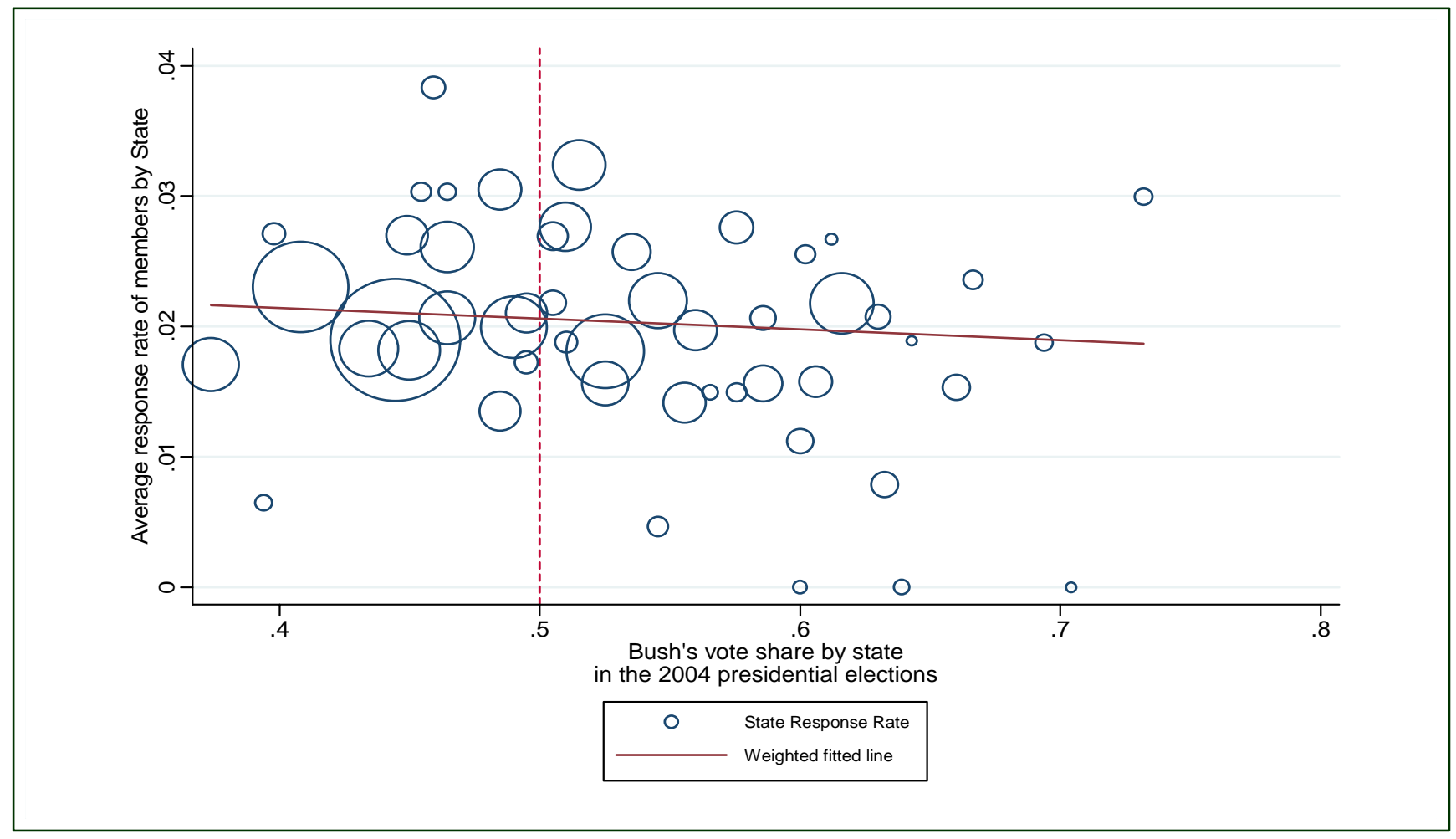

Figure 3

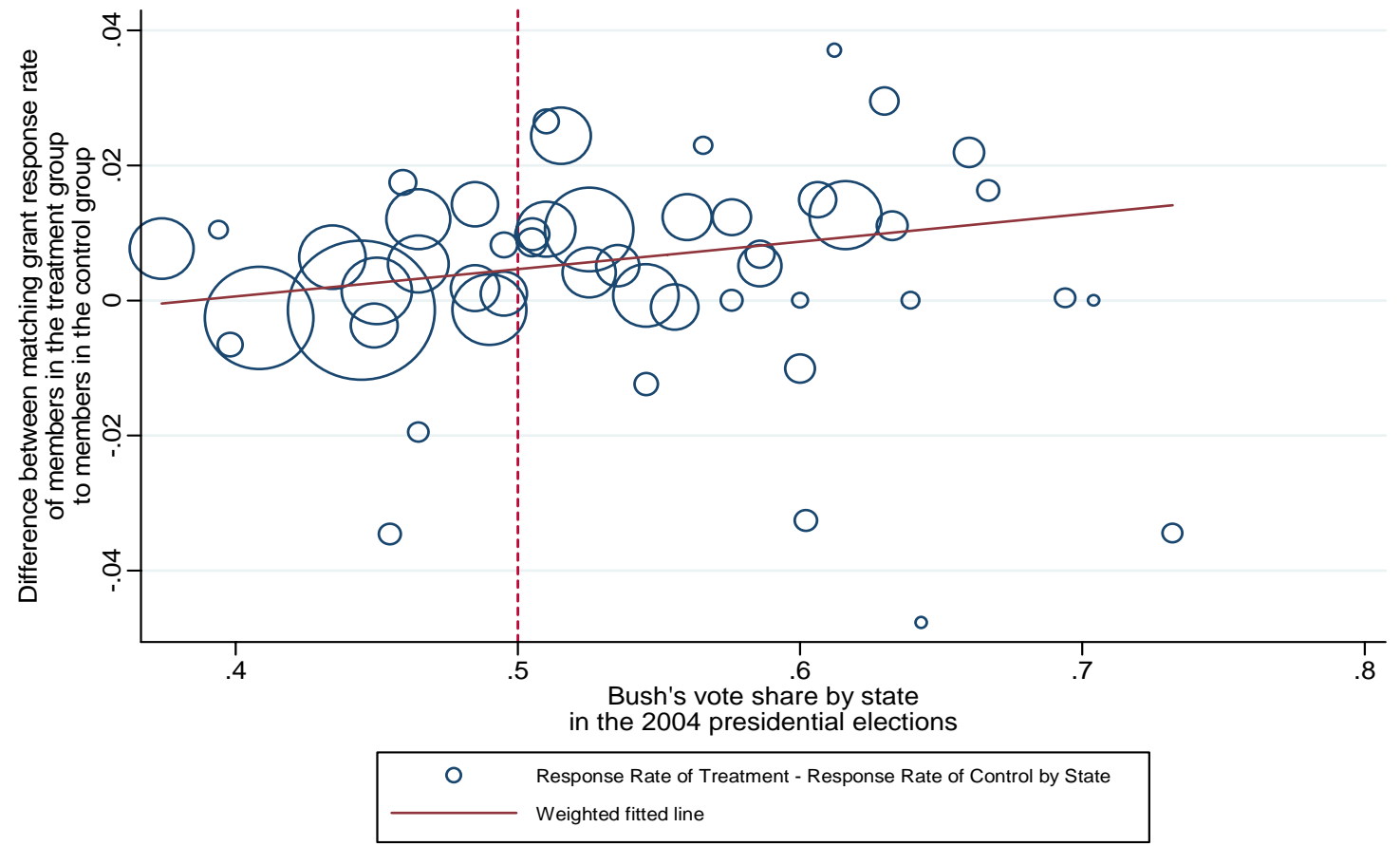

